Available online: https://journals.researchsynergypress.com/index.php/ijeass

International Journal of Entrepreneurship and Sustainability Studies (IJEASS)

ISSN 2807-1778(Online)| 2807-1921 (Print)

Volume 1 Number 2 (2021): 28-34

\title{
Analysis of Entrepreneurial Competency in East Java
}

\author{
Esti Nalurani' ${ }^{1}$, Fendy Suhariadi ${ }^{1}$, Rahma Sugihartati ${ }^{1}$ \\ ${ }^{1}$ Universitas Airlangga, Indonesia
}

\begin{abstract}
Based on the 2018 Global Entrepreneurship Index's data, globally, Indonesia is a country that has a low number of entrepreneurs, which position in 94 from 137 countries. Meanwhile, entrepreneurs have an important role in supporting the national economy in various aspects. Indirectly, they are required to have more competence to compete and survive longer. This research finds out the relevance of 30 characteristics in the three-cluster entrepreneurial competence block diagram for entrepreneurs in East Java. The authors use the qualitative method with the Miles and Huberman analysis technique. This data was collected by interviewing 11 entrepreneurs who have been selected based on the criteria. With the approach of Miles and Huberman, the researcher concluded that 11 entrepreneurs had 30 entrepreneurial characteristics and considered that these characters were important. The results identify that 30 characteristics in the three-cluster entrepreneurial competency block diagram are valid. In addition, the competence of entrepreneurs can be through a religious approach and the culture of the surrounding community. And during the pandemic, entrepreneurial competence is more relevant with the government and society support.
\end{abstract}

Keywords: East Java, Entrepreneur, Entrepreneurial Competencies

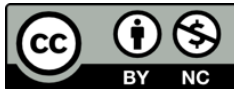

This is an open access article under the CC-BY-NC license.

\section{INTRODUCTION}

Nowadays, entrepreneurship is recognized as a vital component in achieving a country's economic and social success because it encourages economic expansion, productivity, innovation, and employment (Fredericket al. (2018) in the research journal Liu, al. (2019)). As a result, it has aroused interest in promoting entrepreneurship to the public over the past three decades (Parker, 2018; Liu, al., 2019). In Indonesia, the development in entrepreneurship is a strategic need to increase economic resilience. According to Saptono et al. (2016), one of the characteristics of economic resilient is the growth of entrepreneurs who can apprehend and develop all business opportunities.

Based on the Global Entrepreneurship and Development Institute data (GEDI, 2020), globally, Indonesia is ranked 94th out of 137 countries. This success was obtained by Indonesia because it increased the value of GCI (Global Competitiveness Index) in terms of the number of entrepreneurs. Entrepreneurship becomes the first element of economic growth and development in all countries (Meyer \& Hamilton, 2020; Mcaleer, 2019).

Entrepreneurs are agents of change in the economy. A competent entrepreneur must have business knowledge, play a social role, be creative, have enthusiasm and motivation, be a good planner, dare to take risks, and have problem-solving skills (Pepple and Enouh, 2020). The complex environment, high competition in the business world, and increasingly rapid business growth are 
the reasons behind the importance of entrepreneurial competence. And entrepreneurs are increasingly being challenged to improve their competencies to succeed in entrepreneurial activities (Brinckmann, 2008; Pepple and Enouh, 2020).

Competent entrepreneur has their characteristics. It uses when faced dealing complex situations because it can strengthen perceptions, build innovation, business growth, and develop organizational resource capabilities. The pandemic has disturbed the economic sector, especially the actors. Moreover, the government policies often change in line with the dynamics of Covid-19. It forces entrepreneurs to be adaptive to stabilize their businesses indirectly.

The research aims to analyze entrepreneurial competencies related to the knowledge, attitudes, and skills around East Java. These competencies are simplified into a three-cluster diagram of entrepreneurial competencies consisting of 30 characteristics (Arafeh, 2016). The research was conducted on 11 entrepreneurs in East Java who were selected based on:

1. Age $>25$ years old

2. Amount of turnover $\geq \mathrm{Rp} 500$ million per year (Small Medium Enterprise classified)

3. Own investments and assets, and

4. Business running $\geq 5$ years

\section{LITERATURE REVIEW}

The competence is illustrated to the person who has more abilities in certain activities and has common sense. According to Baum (2001) in the research journal Sarwoko and Nurfarida (2018), entrepreneurial competence is defined as individual characteristics as the knowledge, skills, and abilities needed to do certain works. It is accordance with Bird (1995) in the research of Tehseen et al. (2018), entrepreneurial competence is defined as the underlying characters such as traits, motives, special knowledge, social roles, skills, and self-image that lead to the birth of new businesses, their survival and growth.

Ahmad et al. (2010) on Behling and Lenzi (2019) emphasize the importance of understanding the role of knowledge, skills, attitudes, and behavior of entrepreneurs and the impact that these personalities have on company performance. The results of an empirical study of 212 SMEs in Malaysia show that entrepreneurial competence has a direct and substantial impact on the company's success. Competence is a very comprehensive construct, encompassing skills and various performance-relevant attributes. Therefore, competence can be goal-oriented (Chell, 2013; Behling and Lenzi, 2019).

Research from Lee et al. (2016) on Gianesini et al. (2018) has identified five dimensions of entrepreneurial competence. It consists of 1) recognizing, developing, and assessing opportunities through insight (Opportunity Competence), 2) operating well and having administrative skills (administrative competence), 3) hiring candidates who can be trained, build trust and healthy relationships with employees, communicate and lead to good corporate culture (Relationship Competence), 4) individual traits that reflected in entrepreneurial behavior (Personal Competence), and 5) have perseverance even in uncertain situations (competency commitment).

\section{RESEARCH METHOD}

This research is qualitative. Because this study aims to explore the competencies possessed by an entrepreneur, the researcher uses the Miles and Huberman approach. This approach is considered 
appropriate because the activities include data reduction, data presentation, and drawing conclusions and levers. The data were obtained using the interview method. In general, the questions asked were about strategy, planning, and the amount of power/strength possessed and presented in 30 in-depth questions.

The sample in this study was taken through in-depth interviews with SMEs (Small Medium Enterprise) consisting of 11 entrepreneurs in East Java. Samples were analyzed based on age, annual turnover, the value of investment/assets, and businesses that have been running for more than 5 years. In addition, it is important to note that FGDs are data that is saturated, in-depth, and known by the 11 entrepreneurs selected by the researchers.

\section{FINDINGS AND DISCUSSION}

The results of the study were based on the researcher's interpretation of the interview results. The results aim to answer the question: "how important are the 30 entrepreneurial characters in the three-cluster diagram to be owned by entrepreneurs". And the results of interviews with 11 respondents were summarized into one more dominant answer and then shown in table 3 along with conclusions and verification. The researcher also analyzes how important cultural and religious characters are owned by entrepreneurs, considering that Indonesia is a country with cultural and religious diversity, which is still considered important.

Based on the three-stage SKECM Model Block Diagram on Arafeh (2016) Journal, every key entrepreneurial competency (KEC) is modeled in the first stage. In the second stage, every cluster of competencies is modeled based on its related KECs. Relation between the KECs (inputs) and their corresponding cluster (output) are represented in this model. And the third stage shows that the three cluster competencies models are fed into the overall entrepreneurial competencies model to produce the overall competency and proficiency of the entrepreneur under consideration. The three-stage SKECM is described in table 1.

Table 1. The Three-Stage SKECM

\begin{tabular}{|c|c|c|c|c|}
\hline No & Stage 1 & Stage 2 & Stage 3 & Stage 4 \\
\hline 1 & Decision Maker & \multirow{3}{*}{ Persistence } & \multirow{15}{*}{ Achievement } & AP1 \\
\hline 2 & Problem Solver & & & AP2 \\
\hline 3 & Leader & & & AP3 \\
\hline 4 & Hard-Worker & \multirow{3}{*}{ Fulfilling Commitment } & & AF1 \\
\hline 5 & Proactive & & & AF2 \\
\hline 6 & Business Focus & & & AF3 \\
\hline 7 & Efficiency-Oriented & \multirow{3}{*}{ Demand for Quality andEfficiency } & & AD1 \\
\hline 8 & Quality Consciousness & & & AD2 \\
\hline 9 & Determined & & & AD3 \\
\hline 10 & Risk-Taking & \multirow{3}{*}{ Taking Calculated Risks } & & AT1 \\
\hline 11 & Risk-Managing & & & AT2 \\
\hline 12 & Desirable & & & AT3 \\
\hline 13 & Opportunity Seeker & \multirow{3}{*}{ Opportunity-Seeking andInitiatives } & & A01 \\
\hline 14 & Innovative & & & $\mathrm{A02}$ \\
\hline 15 & Initiative-Taker & & & A03 \\
\hline 16 & Goal-Oriented & \multirow{3}{*}{ Goal-Setting } & \multirow[b]{4}{*}{ Planning } & PLG1 \\
\hline 17 & Effective Strategist & & & PLG2 \\
\hline 18 & Proper Planner & & & PLG3 \\
\hline 19 & Competitor's Aware & & & PLI1 \\
\hline
\end{tabular}


International Journal of Entrepreneurship and Sustainability Studies (IJEASS), Vol. 1(2), 28-34

Analysis of Entrepreneurial Competency in East Java

Esti Nalurani, Fendy Suhariadi, Rahma Sugihartati

\begin{tabular}{|c|c|c|c|c|}
\hline 20 & Creative & \multirow[t]{2}{*}{ Information-Seeking } & & PLI2 \\
\hline 21 & Information Seeker & & & PLI3 \\
\hline 22 & Systematic Planner & \multirow{3}{*}{ Systematic Planning andMonitoring } & & PLS1 \\
\hline 23 & Performance-Oriented & & & PLS2 \\
\hline 24 & Book-Keeper & & & PLS3 \\
\hline 25 & Persuasive & \multirow{3}{*}{ Persuasion andNetworking } & \multirow{6}{*}{ Power } & POP1 \\
\hline 26 & Influence Strategy User & & & POP2 \\
\hline 27 & Networker & & & POP3 \\
\hline 28 & Independent & \multirow{3}{*}{ Independence and Self-Confidence } & & POI1 \\
\hline 29 & Self Esteem & & & POI2 \\
\hline 30 & Self-Confident & & & POI3 \\
\hline 31 & Culture \& Religion & & & D1 \\
\hline
\end{tabular}

Table 2. Interview Result

\begin{tabular}{|c|c|c|}
\hline No & $\mathbf{s}$ & Result \\
\hline 1 & AP1 & $\begin{array}{l}\text { Overall, resource persons have the ability to make every decision. This is shown based onthe } \\
\text { answer that entrepreneurs make decisions directly, especially on critical issues. This } \\
\text { shows that an entrepreneur is a decision-maker }\end{array}$ \\
\hline 2 & AP2 & $\begin{array}{l}\text { Overall, resource persons are able to solve problems by involving other people. This is because } \\
\text { employers have entrusted their employees to solve company problems. This shows that an } \\
\text { entrepreneur needs other people to solve problems }\end{array}$ \\
\hline 3 & AP3 & $\begin{array}{l}\text { Resource persons have a leadership spirit, and they agree that an entrepreneur needs tohave it. } \\
\text { This shows that an entrepreneur has a leadership spirit }\end{array}$ \\
\hline 4 & AF1 & $\begin{array}{l}\text { The resource person is a hard worker. This is evidenced by working more than } 8 \text { hours aday, even } \\
\text { sacrificing their rest time. this shows that an entrepreneur has a hardworking } \\
\text { character }\end{array}$ \\
\hline 5 & AF2 & ive \\
\hline 6 & AF3 & $\begin{array}{l}\text { Overall, the informants already have a plan for the next } 5 \text { years for their company. thisshows } \\
\text { that an entrepreneur must focus on business life }\end{array}$ \\
\hline 7 & AD1 & $\begin{array}{l}\text { Resource persons make deadlines in completing each job. this shows that an entrepreneuris } \\
\text { committed to time and everything involved in the work }\end{array}$ \\
\hline 8 & AD2 & $\begin{array}{l}\text { Of the } 11 \text { interviewees, all of them agreed to monitor the employee's performance on adaily } \\
\text { basis. This is due to their focus on producing good products and services. thus } \\
\text { showing that an entrepreneur has quality-consciousness }\end{array}$ \\
\hline 9 & AD3 & $\begin{array}{l}\text { Of the } 11 \text { sources, all of them have a strong mentality when they fail. It is evident that they } \\
\text { immediately devised a new strategy to remedy this shortcoming. thereby showing that an } \\
\text { entrepreneur has a firm character }\end{array}$ \\
\hline 10 & AT1 & $\begin{array}{l}\text { Of the } 11 \text { sources, many said that risk is something that must be faced. It is evident that they are } \\
\text { not afraid and feel challenged to take on risky jobs. thereby showing that an entrepreneur has a } \\
\text { risk-taking character }\end{array}$ \\
\hline 11 & AT2 & $\begin{array}{l}\text { Each time they plan a new strategy, } 11 \text { resource persons will observe the risks that will be faced } \\
\text { and how to overcome them. This shows that almost all entrepreneurs have good risk management }\end{array}$ \\
\hline 12 & AT3 & $\begin{array}{l}11 \text { resource persons admitted that they liked their work as entrepreneurs. And they hope } \\
\text { that the business will last longer. This shows that entrepreneurs have a desire for business }\end{array}$ \\
\hline 13 & A01 & $\begin{array}{l}11 \text { resource persons said that they often visit creative business events to see the potential around } \\
\text { them and find out business opportunities that can be exploited. This shows that entrepreneurs } \\
\text { have an opportunity-seeker character }\end{array}$ \\
\hline
\end{tabular}


International Journal of Entrepreneurship and Sustainability Studies (IJEASS), Vol. 1(2), 28-34

Analysis of Entrepreneurial Competency in East Java

Esti Nalurani, Fendy Suhariadi, Rahma Sugihartati

\begin{tabular}{|c|c|c|}
\hline 14 & AO2 & $\begin{array}{l}11 \text { interviewees said that they took advantage of developing technology to increase business value. } \\
\text { They have a company website or take advantage of a business platform to increase sales and } \\
\text { demand. This shows that entrepreneurs have an innovative character }\end{array}$ \\
\hline 15 & A03 & $\begin{array}{l}11 \text { interviewees said that they took advantage of developing technology to increase business value. } \\
\text { They have a company website or take advantage of a business platform to } \\
\text { increase sales and demand. This shows that entrepreneurs have an innovative character }\end{array}$ \\
\hline 16 & PLG1 & $\begin{array}{l}\text { Almost all of the informants admit that they are results-oriented. But remain flexible in } \\
\text { circumstances. This shows that entrepreneurs are goal-oriented towards business }\end{array}$ \\
\hline 17 & PLG2 & $\begin{array}{l}11 \text { sources say that they can market their products based on place and type of consumer. This } \\
\text { shows that entrepreneurs have an effective strategic character }\end{array}$ \\
\hline 18 & PLG3 & $\begin{array}{l}11 \text { resource persons said that they divided the work among employees according to their job } \\
\text { description, but some employers open up opportunities for other employees to do work outside } \\
\text { their jobdesc. It aims to increase the skills of each employee. This shows that } \\
\text { entrepreneurs have a proper planner character }\end{array}$ \\
\hline 19 & PLI1 & $\begin{array}{l}\text { All informants know the existence of business competitors in the same industry. This shows that } \\
\text { an entrepreneur has a competitors' aware character }\end{array}$ \\
\hline 20 & PLI2 & or information from their coworkers. This show \\
\hline 21 & PLI3 & $\begin{array}{l}11 \text { entrepreneurs follow developments that occur every day through social media. In addition, } \\
\text { some like to discuss activities with colleagues to get new information. It can be } \\
\text { said that an entrepreneur has a good information seeker character }\end{array}$ \\
\hline 22 & PLS1 & $\begin{array}{l}\text { In solving problems, almost all sources describe problems and seek accurate information to make } \\
\text { it easier to achieve goals. They also involve employees to solve common problems. This shows that } \\
\text { an entrepreneur has a good systematic planner character }\end{array}$ \\
\hline 23 & PLS2 & $\begin{array}{l}\text { Between performance and results, } 11 \text { entrepreneurs agreed to focus on improving performance } \\
\text { and then expect results. They believe that good performance will result in } \\
\text { satisfactory results. This shows that an entrepreneur has a performance-oriented character }\end{array}$ \\
\hline 24 & PLS3 & $\begin{array}{l}\text { Between performance and results, } 11 \text { entrepreneurs agreed to focus on improving performance } \\
\text { and then expect results. They believe that good performance will result in satisfactory results. This } \\
\text { shows that an entrepreneur has a performance-oriented character }\end{array}$ \\
\hline 25 & POP1 & $\begin{array}{l}11 \text { entrepreneurs have a good ability to convince consumers or co-workers to cooperate. } \\
\text { On some occasions, they are able to pass projects or sales with consumers. This shows that an } \\
\text { entrepreneur has a good persuasive character }\end{array}$ \\
\hline 26 & POP2 & $\begin{array}{l}11 \text { entrepreneurs have good skills in promoting their products. Some of them believe in the } \\
\text { practice of word of mouth to market the product. This shows that an entrepreneur has a good } \\
\text { influence strategy user character }\end{array}$ \\
\hline 27 & POP3 & $\begin{array}{l}11 \text { entrepreneurs have more than } 10 \text { colleagues. They agree that connections help them gain } \\
\text { information or increase sales. This shows that an entrepreneur is able to build a good networker }\end{array}$ \\
\hline 28 & POI1 & $\begin{array}{l}\text { Almost all entrepreneurs prefer to get the job done on their own without bossing others around. } \\
\text { This shows that an entrepreneur has an independent character }\end{array}$ \\
\hline 29 & POI2 & $\begin{array}{l}11 \text { entrepreneurs have high ambitions, but not all entrepreneurs hate failure. Some of them think } \\
\text { that failure is a natural thing and can be fixed. This shows that an entrepreneur has a good self- } \\
\text { esteem character }\end{array}$ \\
\hline 30 & POI3 & $\begin{array}{l}11 \text { entrepreneurs are good conversationalists. This statement is evidenced by the activities of } \\
\text { those who have been speakers in various online and offline seminars. This shows that an } \\
\text { entrepreneur has a good self-confident character }\end{array}$ \\
\hline
\end{tabular}




\begin{tabular}{|l|l|l|}
\hline & & $\begin{array}{l}\text { The researcher can conclude that } 11 \text { entrepreneurs consider culture and religion as important } \\
\text { variables owned by an entrepreneur. Culture in the work environment can build good } \\
\text { relationships with employees, consumers, or the community. in addition to } \\
\text { building a good business image. and religion is important because they believe that God has a big } \\
\text { hand in every success }\end{array}$ \\
\hline
\end{tabular}

Nowadays, the entrepreneurial attitude will determine how long the business owned will last, especially during the pandemic, which has a direct impact on economic sectors almost all over the world, including Indonesia. Many entrepreneurs go bankrupt, resulting in entrepreneurs working harder to survive in current conditions. Entrepreneur's competence is one of the important elements that entrepreneurs need to have in order to be more prepared to face various kinds of situations. This is evidenced from 11 entrepreneurs as a research sample whose business persists during pandemic conditions, that all of the samples have good entrepreneurial competencies, which are represented through 30 entrepreneurial characteristics.

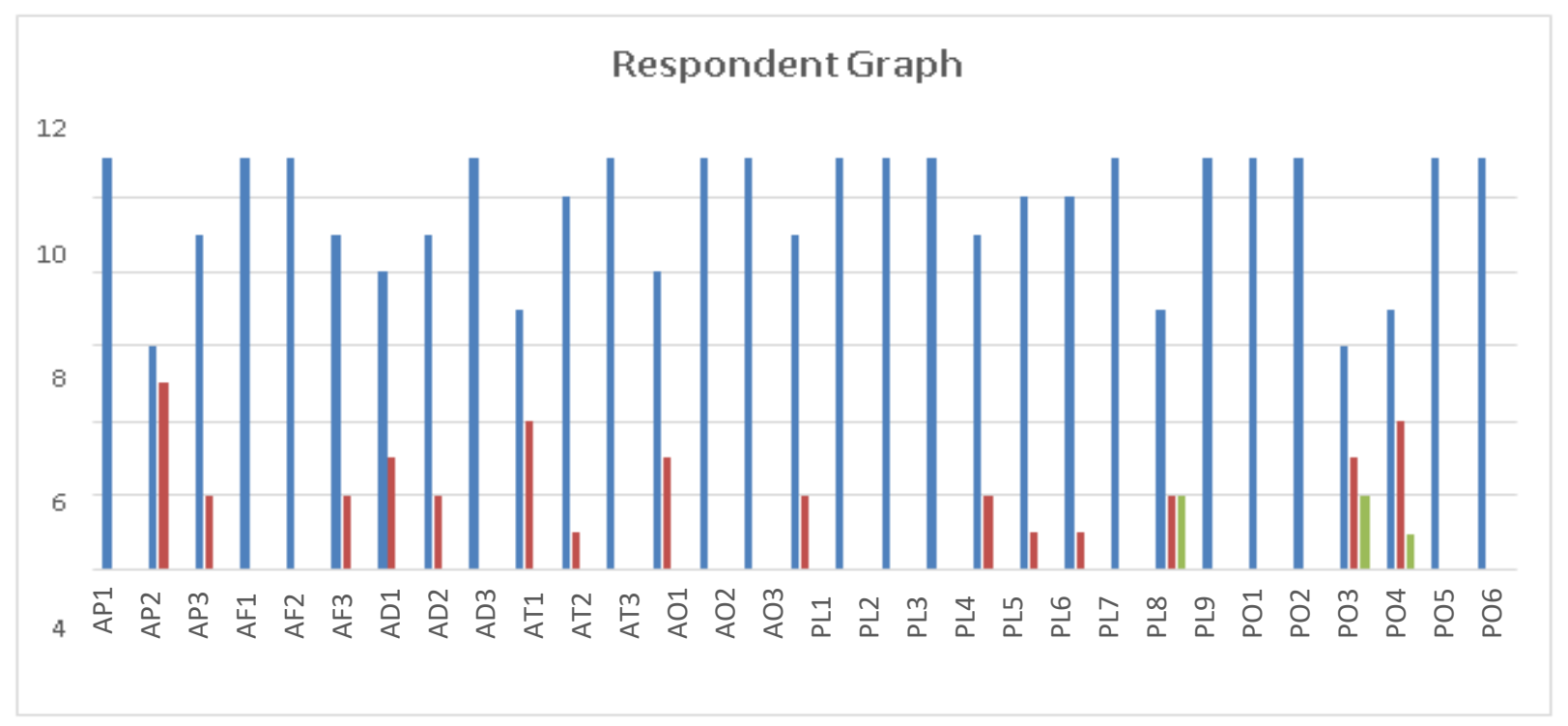

Figure 1. Respondent Graph

This opinion is strengthened through the research of Ilham et al. (2020), which states that young entrepreneurs who are able to survive and thrive in the midst of the Covid-19 pandemic are business actors who have high creativity and innovation by running an online-based business (online marketing platform) primarily by utilizing social media as a means of promotion.

\section{CONCLUSION}

This study was designed to analyze entrepreneurial competencies related to knowledge, attitudes, and skills of entrepreneurs in East Java by involving 30 entrepreneurial characteristics contained in the diagram of the three classifications of entrepreneurial competencies in Arafeh's research (2016). The researcher also involves a religious and cultural approach to the community, seeing that Indonesia is a country that has cultural and religious diversity. And the analysis was conducted on 11 entrepreneurs in East Java classified by age, annual turnover, investment and assets, and business age. With the approach of Miles and Huberman, the researcher concluded that 11 entrepreneurs had 30 entrepreneurial characteristics and considered that these characters were 
important. This is explained in table 2 and graph 1 of the respondents based on the results of indepth interviews with each entrepreneur. Especially when facing the current pandemic situation, the entrepreneurial competencies possessed can make entrepreneurs able to survive. This is evidenced from 11 entrepreneurs as a research sample whose business persists during pandemic conditions, that all of the samples have good entrepreneurial competencies, which are represented through 30 entrepreneurial characteristics. The researcher involved religious and cultural variables, which were considered by 11 sources. The results are by following the researcher's assumption that 11 entrepreneurs in East Java apply customs in their work or social interactions and still have good spiritual.

\section{ACKNOWLEDGEMENT}

In accordance with the publication of the journal made by the researcher, on this occasion, we would like to thank you for your efforts and expertise as a reviewer. Your help allows us to meet scheduled times and maintain peer-review standards journal. Your dedication is greatly appreciated as the number of manuscripts increases every year.

Reviewer:

1. Prof. Dr. Fendy Suhariadi, M.T., Psychologist, Airlangga University Surabaya, Indonesia

2. Dr. Rahma Sugihartati, Dra., M. Si, Airlangga University Surabaya, Indonesia

\section{REFERENCES}

Arafeh Labib. (2016). An Entrepreneurial Key Competencies' Model. Visual Post: Journal of Innovation and Entrepreneurship, 5(26): 1-26.

Behling Gustavo, Lenzi Fernando Cesar. (2019). Entrepreneurial Competencies and Strategic Behavior: a Study of Micro-Entrepreneurs in an Emerging Country. Visual Post: Brazilian Business Review: 255-272.

Gianesini Giovanna, et al. (2018). Entrepreneurial Competencies: Comparing and Contrasting Models and Taxonomies. Visual Post: Entrepreneurship and The Industry Life Cycle: 13-32.

Ilham, et al. (2020). Kondisi Pengusaha Muda Indonesia Di Tengah Pandemi Covid-19 (Work From Home Dan Strategi Survive). Visual Post: Jurnal Ilmu Pendidikan PKn dan Sosial Budaya, 4(1): 59-68.

Liu Xianyue, et al. (2019). Research on the Effect of Entrepreneurial Education and Entrepreneurial Self-Efficacy on College Students' Entrepreneurial Intention. Visual Post: College Students' Entrepreneurial Intention, 10: 869.

Pepple Grace Jamie, Enough Rebecca Oliver. (2020). Entrepreneurial Competencies: A Required Skill For Business Performance. Visual Post: European Journal of Business and Innovation Research, 8(3): 50-61.

Saptono Ari, Purwana Dedi. (2016). Learning Environment, Self-Efficacy, And Attitude Impact Vocational Students' Entrepreneurial Intention. Visual Post: 2(1): 50-60.

Sarwoko Endi, Nurfarida Iva Nurdiana. (2018). Entrepreneurial Orientation and Entrepreneurial Competency of Small and Medium Entreprises. Visual Post: Annual Conference on Social Sciences and Humanities: 527-530.

Tehseen Shehnaz, et al. (2018). Entrepreneurial Competencies and SME's Growth: The Mediating Role of Network Competence. Visual Post: Asia-Pasific Journal of Business Administration, 11(1): 2-29. 